\title{
Thoracic scent efferent system and exponium of Aphylidae (Hemiptera: Heteroptera: Pentatomoidea), its architecture and function
}

\author{
Petr KMENT ${ }^{1}$, PAVEL ŠTYS² and JitKa VILÍMOVÁ \\ ${ }^{1}$ Department of Entomology, National Museum, Kunratice 1, CZ-148 00 Praha 4 - Kunratice, Czech Republic; \\ e-mail: sigara@post.cz \\ ${ }^{2}$ Charles University in Prague, Faculty of Science, Department of Zoology, Viničná 7, CZ-128 44 Praha 2, Czech Republic; \\ e-mails: pavelstys@gmail.com, vilim@natur.cuni.cz
}

Key words. Heteroptera, Pentatomoidea, Aphylidae, morphology, thorax, exponium, efferent system of metathoracic scent glands, antipredatory behaviour

\begin{abstract}
The external morphology of Aphylidae was studied previously in detail by the two junior authors, including the description of unique derived structures formed by their lateral thoracico-abdominal region (the exponium). Here we provide an additional description of the external scent efferent system of the metathoracic scent glands of species in the genus Aphylum Bergroth, 1906 (based on scanning electron microscope study) and its connection with an autapomorphic aphylid thoracico-abdominal region, the exponium. The origins of exponial sclerites are discussed and function of the exponium is hypothesised as being part of a complex defensive mechanism in the Aphylidae.
\end{abstract}

\section{INTRODUCTION}

The insect clade Heteroptera is explicitly characterized by autapomorphic pattern of repellent scent glands (Schuh \& Slater, 1995; Weirauch, 2006a, b), the dorsal abdominal scent glands in the larvae, often persistent in adults (summarized by Weirauch, 2006b), and the metathoracic scent glands (= MTGs) in the adults (at least in Neoheteroptera). The names of glands clearly express their usual somatic position. The primary functions of the metathoracic scent gland secretion are repugnatorial and defensive; bactericid, fungicid or pheromonal functions are probably secondary. The external scent efferent system (see terminology in Material and Methods) serves for rapid ejection and evaporation of the repellent secretion and simultaneously for protection of the specimen against toxicity of its own secretion (for chemism see, e.g., Staddon, 1979, 1986; Aldrich, 1988). The external scent efferent system of the metathoracic scent glands in the adult Pentatomomorpha, particularly the Pentatomoidea, has been recently studied in detail by Kment \& Vilímová (2010a, b).

The Aphylidae is a small clade of Pentatomoidea endemic to Australia, including only two genera and three described species: Aphylum Bergroth, 1906 with A. syntheticum Bergroth, 1906 (New South Wales, South Australia, Victoria) and A. bergrothi Schouteden, 1906 ("Australia"), and Neoaphylum Štys \& DavidováVilímová, 2001 with $N$. grossi Štys \& DavidováVilímová, 2001 (Western Australia) (Cassis \& Gross, 2002).

Štys \& Davidová-Vilímová (2001) provided a detailed diagnostic description and discussion of some aspects of the external morphology of both Aphylum and Neoaphylum, especially the modified lateral parts of thorax and abdomen that form an exponium. The new term "exponium" was derived from the Latin verb exponere (= to expose, to exhibit) by adding termination -ium, thus forming a neuter noun. It was coined to refer to a group of three (Aphylum) or four (Neoaphylum) sclerites (called "exponial sclerites" and indicated by acronymic abbreviations) freely visible in dorsolateral view. The exponium is situated in a space delimited by the pronotum (anteriorly), resting forewing (mesally) and dorsal abdominal laterotergites (posteriorly; in Neoaphylum also by dorsally shifted ventral abdominal laterotergites); lateral margin of the exponium is free. For details and terminology see Table 1. Presence of the exponium is a diagnostic autapomorphy of the Aphylidae, and it has been noticed by all the authors ever concerned with this taxon, but not named and not precisely homologized prior to Štys \& DavidováVilímová (2001).

Štys \& Davidová-Vilímová (2001) showed that exponium is formed by transformed lateral elements of thorax and abdominal basis, which are closely associated and externally exposed. The exponium was then regarded as of unknown function. The authors also described part of the external scent efferent system of the metathoracic scent glands, not paying any attention to the microsculpture.

Herein we are concerned with a detailed examination of the external scent efferent system in the Aphylidae using scanning electron microscope, particularly in elucidation of the architecture and possible function of the exponium - a structure that is closely associated with and forms a part of the external scent efferent system, and hypothesise the possible function of this unique formation. Admittedly, we do not possess any observation (the less any experimental evidence) of the actual function of the struc- 
TABLE 1. Review of the exponial sclerites in the Aphylidae. Based on Štys \& Davidová-Vilímová (2001).

\begin{tabular}{|c|c|c|c|c|}
\hline Sclerite & & Position & Origin & Occurrence \\
\hline $\begin{array}{l}\text { Anterior } \\
\text { mesal } \\
\text { exponial } \\
\text { sclerite }\end{array}$ & MES & $\begin{array}{l}\text { Situated above the mesepisternum and associated with hindwing articula- } \\
\text { tion and medio-tergites } 1 \text { and } 2 \text { basis, always lacking the puncturation of } \\
\text { LES and TES, and always subdivided in two parts. Its mesal region cov- } \\
\text { ered by forewings (accommodating the hypocostal lamina), anterior } \\
\text { margin contacting the pronotum, lateral and posterior margins either } \\
\text { engulfed by LES (Aphylum), or the lateral one free and the posterior one } \\
\text { contacting PMES (Neoaphylum). With mycoid microsculpture. }\end{array}$ & $\begin{array}{l}\text { Dorsal part of meta- } \\
\text { pleuron reflected onto } \\
\text { dorsum - mesepi- } \\
\text { sternum and mesepi- } \\
\text { meron in Aphylum or } \\
\text { mesepisternum only in } \\
\text { Neoaphylum. }\end{array}$ & $\begin{array}{l}\text { Aphylum, } \\
\text { Neoaphylum } \\
\text { (Figs 2, 4, 7) }\end{array}$ \\
\hline $\begin{array}{l}\text { Posterior } \\
\text { mesal } \\
\text { exponial } \\
\text { sclerite }\end{array}$ & PMES & $\begin{array}{l}\text { Interspaced between AMES and LES sharing with them the same gross } \\
\text { sculpturation; it is a flap-like projection situated just above the mesepi- } \\
\text { meron cephalad the metathoracic spiracle. }\end{array}$ & $\begin{array}{l}\text { Dorsally reflected part } \\
\text { of mesepimeron. }\end{array}$ & $\begin{array}{l}\text { Neoaphylum } \\
\text { (Fig. 4) }\end{array}$ \\
\hline $\begin{array}{l}\text { Lateral } \\
\text { exponial } \\
\text { sclerite }\end{array}$ & LES & $\begin{array}{l}\text { Continuous with metepisternum, its lateral margin forming a part of lat- } \\
\text { eral body margin; subdivided into a dorsal area and a lateral, subvertical } \\
\text { area (= "modified lateral part of LES"), the latter being overlapped by the } \\
\text { pronotum and bipartite (Aphylum), or fitting its margin and entire } \\
\text { (Neoaphylum); mesal margin covered by forewing and forming anterior } \\
\text { part of forewing groove jointly with abdominal mediotergites } 1 \text { and } 2 \text {. }\end{array}$ & $\begin{array}{l}\text { Metepisternal- } \\
\text { metapostnotal origin. } \\
\text { "Modified lateral part" } \\
\text { is definitely metepi- } \\
\text { sternal. }\end{array}$ & $\begin{array}{l}\text { Aphylum, } \\
\text { Neoaphylum } \\
\text { (Figs 2, 4, 7) }\end{array}$ \\
\hline $\begin{array}{l}\text { Triangular } \\
\text { exponial } \\
\text { sclerite }\end{array}$ & TES & $\begin{array}{l}\text { Anterior margin contacting LES, posterior margin contacting dorsal } \\
\text { abdominal laterotergite } 3 \text { (Aphylum), or both ventral abdominal lateroter- } \\
\text { gites } 2 \text { and } 3 \text { and dorsal abdominal laterotergite } 3 \text { (Neoaphylum); mesal } \\
\text { margin as in LES, taking part in formation of the posterior part of } \\
\text { forewing groove. }\end{array}$ & $\begin{array}{l}\text { Dorsal abdominal } \\
\text { laterotergites } 1 \text { and } 2 .\end{array}$ & $\begin{array}{l}\text { Aphylum, } \\
\text { Neoaphylum } \\
\text { (Figs 2, 4, 7) }\end{array}$ \\
\hline
\end{tabular}

tures concerned in live individuals - we can only generalize from situations known in other Heteroptera. However, we prefer to provide a viable and potentially heuristically stimulating hypothesis rather than become limited by a mere description.

\section{MATERIAL AND METHODS}

The following specimens were examined: "Aphylum sp.1 cf. bergrothi": \&, Australia, Queensland, Clermont, viii.[19]28, Dr. K.K. Spence lgt., A. Musgrave det. as A. bergrothi (Coll. Australian Museum, Sydney, Australia) [used for line drawings]; "Aphylum sp. 2": 0 , Australia, New South Wales, Bogana, no date, J. Armstrong lgt. (Coll. Australian Museum, Sydney, Australia) [SEM micrographs]. For further comparison we studied also the specimens already used by Štys \& Davidová-Vilímová (2001): “A. sp. 3 cf. syntheticum": + , South Australia, Chovilla Dam, May 1967, R. Edwards lgt., G.F. Gross det. as A. syntheticum (coll. Australian National Collection of Insects, Canberra, Australia); Neoaphylum grossi Štys \& Davidová-Vilímová, 2001: holotype: \$, Western Australia, N Agri-

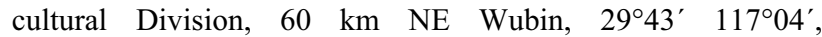
27.ix.1981, I.D. Naumann \& J.C. Cardale lgt. (coll. Australian National Collection of Insects, Canberra, Australia). For explanatory notes on identification see Discussion.

Line drawings of thoracic pleuron were made using stereomicroscope with an attached camera lucida. Scanning electron microscope (SEM) micrographs were prepared in the Laboratory of Electron Microscopy, Biological Section, Faculty of Sciences, Charles University in Prague, using JEOL 6380 LV SEM. Prior to SEM examination, the specimen was coated with gold.

Kment \& Vilímová $(2010 a$, b) recently defined the basic terms related to the MTG and associated structures: The metathoracic scent apparatus consists of internal parts, and the thoracic scent efferent system, further differentiated into internal (internal orifice and vestibule) and external parts. The external scent efferent system consists of ostiole, peritreme, and evapora- torium. The terminology follows these authors for the external scent efferent system, and Štys \& Davidová-Vilímová (2001) for the other thoracic structures. For terminology related to the exponial sclerites see Table 1 and Figs 1-4.

Our (re)description of the exponium differs in several points from that by Štys \& Davidová-Vilímová (2001), but it would be overly pedantic to enumerate all the points of difference; the present text should be regarded as authoritative. The Figs 1-4 have been taken from Štys \& Davidová-Vilímová (2001: Figs 13-16) with only part of the lettering altered.

\section{RESULTS}

Exponium of Aphylum spp. is composed of three sclerites distinguishable and described in lateral body view, the anterior mesal exponial sclerite (AMES), lateral exponial sclerite (LES), and triangular exponial sclerite (TES) (Figs 7-9, Table 1).

Anterior mesal exponial sclerite (AMES) is located most anteriorly, situated between pronotum (anterior edge of AMES loosely fitting the sublateral indentation of the posterior margin of pronotum), proximal part of the costal margin of resting forewing (see below) and LES. It is of an approximately trapezoid outline, its lateral margin bends ventrad and mesad toward the ventral surface of a nearly horizontal mesepimeron, the lateral margin medially provided with a Y-shaped incision making AMES more or less bipartite. The incision is forming the lateral end of evaporatory channel - an impressed groove leading towards the lateral margin of metathoracic spiracle. Surface of AMES is slightly rumpled, its ventral part bearing mycoid microsculpture (Fig. 12) gradually merging with lightly punctured sculpture of its dorsal part contacting forewings (Figs 10-11). The dorso-mesal part of AMES is covered by forewing and bears a distinct groove parallel with the mesal margin of AMES and ter- 

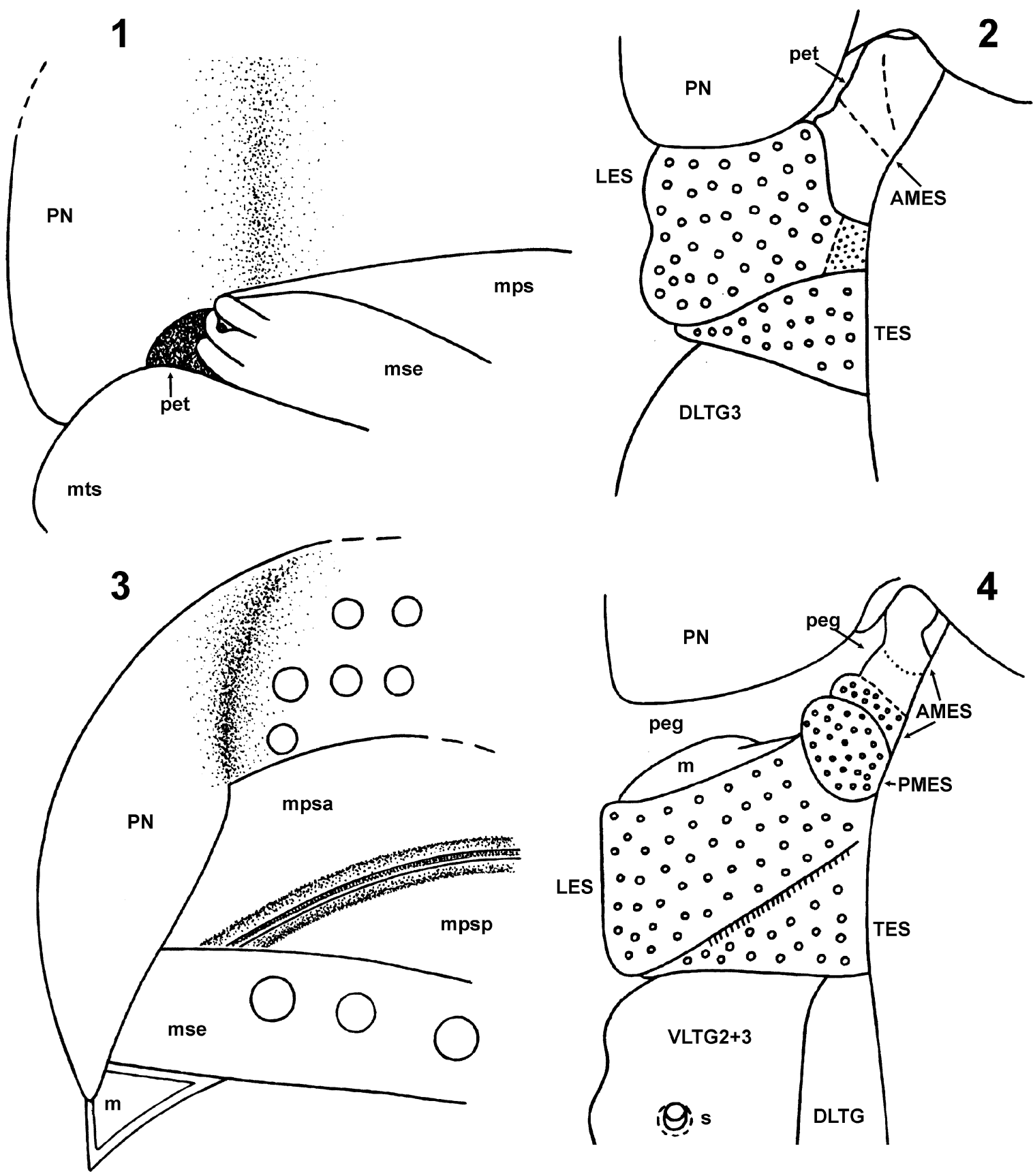

Figs 1-4. 1-2 - A. sp. 3 cf. syntheticum; 3-4 - Neoaphylum grossi Štys \& Davidová-Vilímová, 2001. 1, 3 - Mesopleuron (lateral parts), and its relation to ventral side of prothorax, right side, mesoventral view. 2, 4 - exponium and associated structures, most exposed view (dorsal in A. sp. 3 cf. syntheticum, lateral in N. grossi). Abbreviations: AMES - anterior mesal exponial sclerite, DLTG(3) - dorsal abdominal laterotergite (3), LES - lateral exponial sclerite, $\mathrm{m}$ - modified part of LES, mps - mesepisternum, mpsa - premesepisternum, mpsp - postmesepisternum, mse - mesepimeron, mts - metepisternum, peg - pronotal-exponial gap, pet - pronotal-exponial tunnel, PMES - posterior mesal exponial sclerite, PN - pronotum, s - spiracle, TES - triangular exponial sclerite, VLTG2+3 - ventral abdominal laterotergites 2+3. Modified from Štys \& Davidová-Vilímová (2001, Figs 13, 15, 14, 16, respectively).

minating caudally in a deep fovea. The groove serves for holding the exceedingly short hypocostal lamina of forewing and the fovea accommodates its abrupt denticleshaped termination, functioning obviously as a dorsally shifted druck-knopf mechanism. The part of AMES covered dorsally by forewing contacts mesally the articulatory apparatus of hindwing and fused abdominal mediotergites 1 and 2 .
Lateral exponial sclerite (LES) is the largest of the exponial sclerites, situated slightly obliquely between pronotum, resting forewings and TES, of oblong outline with a posterodorsal projection towards the costal margin of forewing and a wide topographically postero-ventral lobe identical with metepisternum. LES exceeds pronotum ventrally (Figs 7,9). LES is almost flat, with puncturation (Figs 9-10) roughly identical with that on all the 

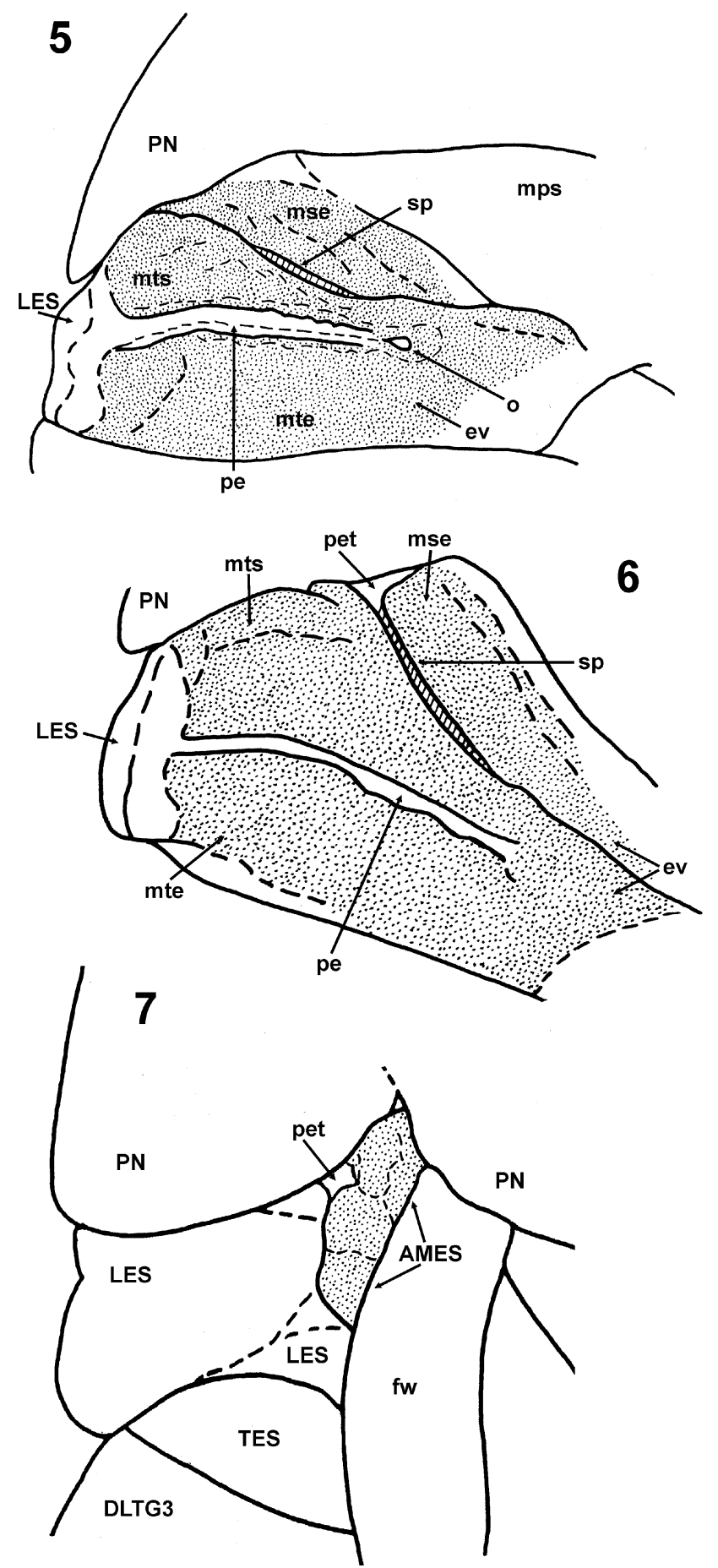

Figs 5-7. Aphylum sp. 1 cf. bergrothi (all magnifications $50 \times$ ): 5 - venter of thorax in ventral view, 6 - venter of thorax in anteroventral view, 7 - lateral part of thorax and abdominal base in dorsal view. Abbreviations: AMES - anterior mesal exponial sclerite (dotted), DLTG3 - dorsal abdominal laterotergite 3 , ev - evaporatorium (dotted), fw - forewing, LES - lateral exponial sclerite, mps - mesepisternum, mse - mesepimeron, mte - metepimeron, mts - metepisternum, o - ostiole, pe - peritreme, pet - pronotal-exponial tunnel, $\mathrm{PN}$ - pronotum, $\mathrm{sp}$ - metathoracic spiracle, TES - triangular exponial sclerite.

dorsum and lateral parts of the body and TES (Fig. 8). Punctures are sparser dorso-posteriorly than on rest of sclerite surface (Fig. 9). Lateral margin of dorsum of LES is sharply defined and forming a boundary between LES proper (metapostnotal origin) and metepisternum.

Triangular exponial sclerite (TES) is named after its triangular outline, with apex pointing ventrally, located between LES, resting forewings and dorsal abdominal laterotergite 3 (Figs 7-9). TES is almost flat, with puncturation, roughly identical with those on all the dorsum, lateral parts of body and LES (Fig. 9).

Mesal margins of LES and TES are covered by costal margin of resting forewing (distal to termination of hypocostal lamina) and forming lateral part of forewing groove (its mesal part being formed by lateral margin of fused abdominal mediotergites 1 and 2).

There is a space between the ventrally expanded lateral parts of pronotum and the exponium, the pronotalexponial gap (Figs 1-2, 7-9: pet, 4, 14-15, 17: peg). In Aphylum spp., the gap is enclosed by lateral expansion of the pronotum, ventral margin of AMES and anterior margin of LES. The internal portion of the pronotalexponial gap in Aphylum forms a nearly closed pronotalexponial tunnel between the ventral margin of AMES and the postero-median margin of pronotum in lateral view (Figs 8-11: pet), and posterior margin of pronotum, lateral margin of mesepimeron and anterior margin of metepisternum in ventral view (Figs 14-19: pet). The remaining lateral portion of the pronotal-exponial gap is obscured in lateral view by the posterior pronotal margin overlapping the anterior margin of LES but could be seen in ventral view (Figs 14, 17: peg), its width depending on the adduction / retraction of pronotum towards pterothorax.

The pronotal-exponial tunnel appears as an elongate rectangular opening in lateral view (Figs 8-11: pet) or triangular opening in ventral view (Figs 14-19: pet) and allows passing of the metathoracic scent gland secretion from ventral to lateral external surface of the body.

Thoracic pleura medially and posteriorly rather flat to slightly concave, anteriorly and particularly laterally emarginate owing to flat and expanded margins of pronotum and metathorax (LES) (Figs 1, 3, 5-6, 8, 13-15). Mesopleuron laterally narrowed. Mesepimeron laterally bent dorsally, squeezed under the expanded pronotal margin (Figs 5-6, 14-18: mse) and turning onto the outer surface of body as AMES (Figs 7-10: AMES). Metepisternum slightly widened anterolaterally, concave, regularly curving ventrally towards its lateral margin (Figs 5-6, 14-17: mts); lateral margin of metepisternum merging with lateral (ventral) margin of LES (Figs 5-6, 16-17, 23: mts, LES). There is a free space between the lateral margin of mesepimeron, the adjacent anterolateral margin of metepisternum and an expanded lateral pronotal margin, the pronotal-exponial tunnel (Figs 6-11, 14-19: pet).

External scent efferent system. Vestibule completely closed, its ventral wall situated between the metacoxa and ostiole, only slightly convex in ventral view (Figs 16-17: ve). Vestibular scar not developed (Figs 5-6, 16-17). Ostiole small, oval (Figs 16-17, 21-22: o), directed ventro-laterally, slightly shifted laterad, situated ca. at lat- 

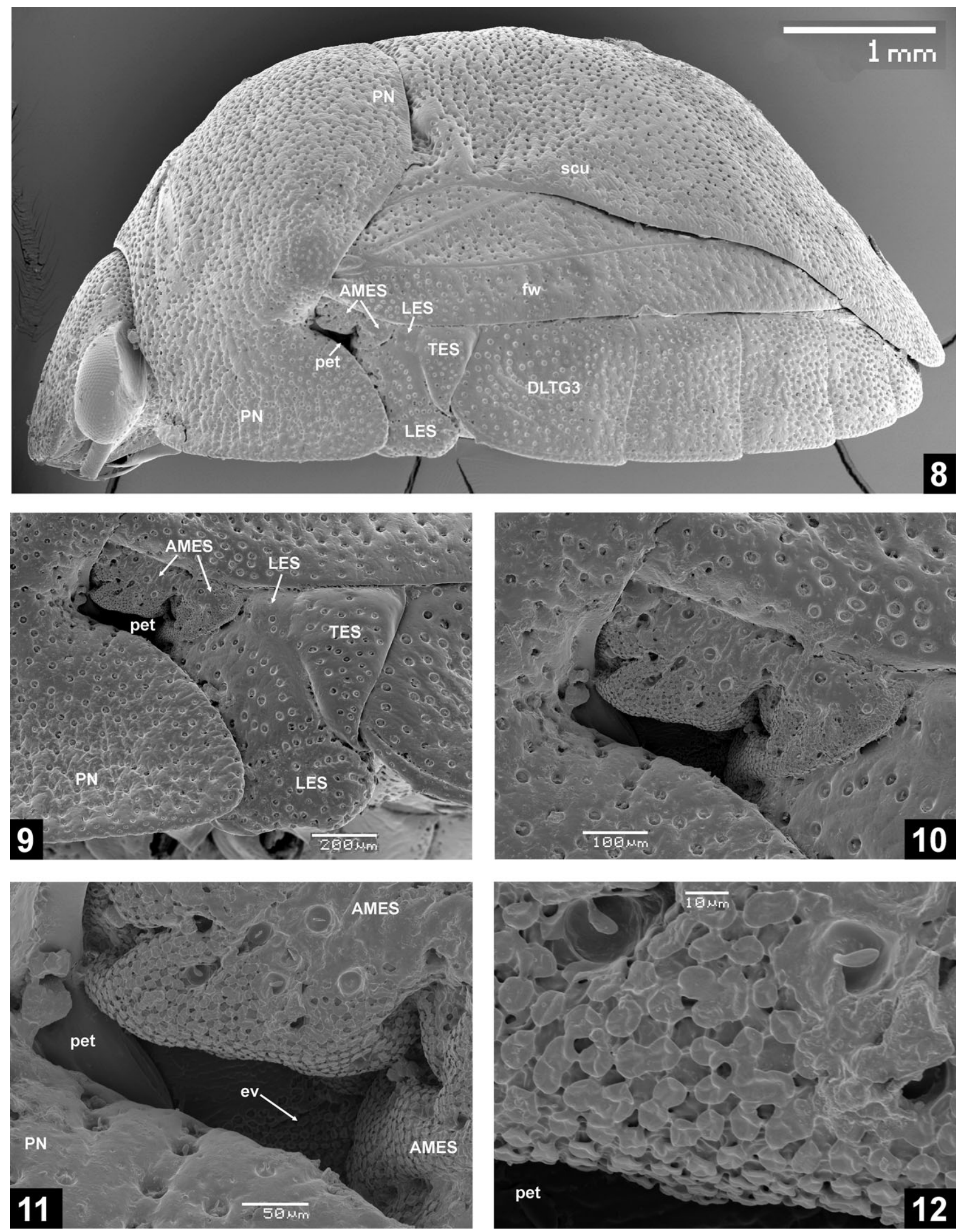

Figs 8-12. Aphylum sp. 2, lateral view: 8 - whole body (magnification $20 \times$ ); 9 - detail of exponium (90×); 10 - detail of pronotalexponial tunnel and AMES (180×); 11 - detail of pronotal-exponial tunnel (370×); 12 - detail of mycoid surface on AMES (anterior portion) $(1200 \times)$. Abbreviations: AMES - anterior mesal exponial sclerite, DLTG3 - dorsal abdominal laterotergite 3, ev - evaporatorium, fw - forewing, LES - lateral exponial sclerite, pet - pronotal-exponial tunnel, PN - pronotum, scu - scutellum, TES - triangular exponial sclerite. 

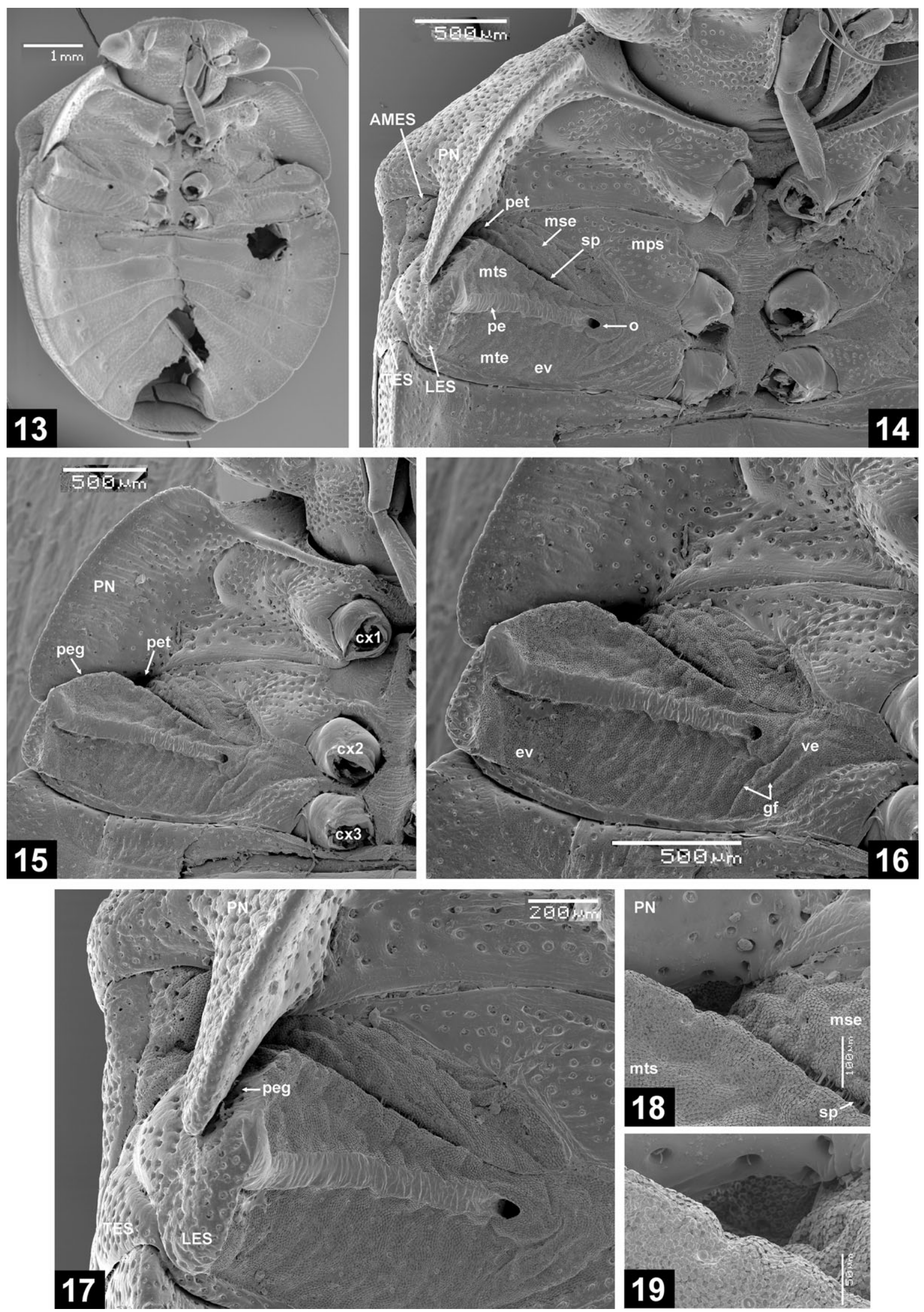

Figs 13-19. Aphylum sp. 2. 13 - ventral surface of body (16×); 14-15 - pleuron (14 - ventro-lateral view, 40×; 15 - ventral view, $35 \times)$; 16-17 - external scent efferent system (16 - ventral view, $65 \times$; 17 - ventro-lateral view, $80 \times)$; 18-19 - details of pronotalexponial tunnel in ventral view $(18-200 \times, 19-400 \times)$. Abbreviations: AMES - anterior mesal exponial sclerite, cx1 - procoxa, cx2 - mesocoxa, cx3 - metacoxa, ev - evaporatorium, gf - furrows forming gyrification, LES - lateral exponial sclerite, mps - mesepisternum, mse - mesepimeron, mte - metepimeron, mts - metepisternum, o - ostiole, pe - peritreme, peg - pronotal-exponial gap, pet - pronotal-exponial tunnel, PN - pronotum, sp - metathoracic spiracle, TES - triangular exponial sclerite, ve - portion of metapleuron covering vestibule. 

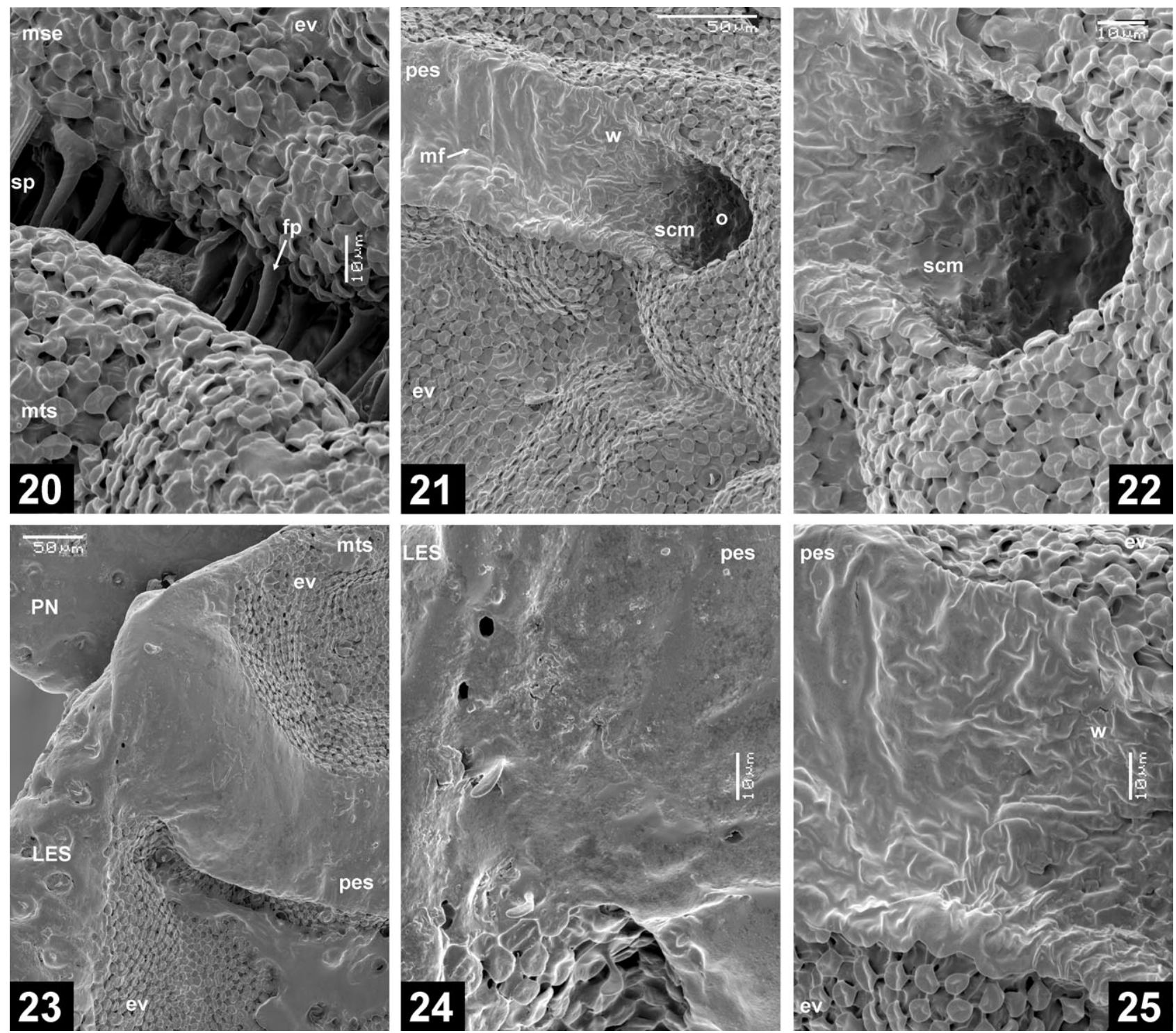

Figs 20-25. Aphylum sp. 2, details of metathoracic spiracle, ostiole and peritreme in ventral view: 20 - metathoracic spiracle with filter processes $(1200 \times) ; 21$ - ostiole and base of peritreme (500×); 22 - ostiole (1200×);23-24 - apex of peritreme $(23-300 \times, 24-$ $1200 \times) ; 25$ - base of peritreme $(1200 \times)$. Abbreviations: ev - evaporatorium, fp - filter processes, LES - lateral exponial sclerite, $\mathrm{mf}$ - median furrow on peritreme, mse - mesepimeron, mts - metepisternum, o - ostiole, pes - peritremal surface, $\mathrm{PN}$ - pronotum, scm - scale-like microsculpture in ostiole, $\mathrm{sp}$ - metathoracic spiracle, $\mathrm{w}$ - wrinkles of peritremal surface.

eral margins of mesacetabulum and metacetabulum, ca. in $1 / 3(0.38: 0.61)$ of the distance from lateral margin of metacoxa towards lateral margin of metepisternum (Figs 5, 13-16: o). Periostiolar depression missing (Figs 16-17). Peritreme shaped as a long, narrow, well emarginated groove, directed laterad, slightly widening distad, and terminating at ventral margin of LES (Figs 5-6, 14-17, 21: pe). Peritreme distinctly elevated above surrounding surface, forming the highest (i.e. most ventral) point of all the pleuron, giving the metepisternum somewhat roof-shaped appearance, sloping both anteriad and posteriad (Fig. 17). The peritremal surface with a deep median furrow (A. sp. 1 cf. bergrothi - Fig. 5) or rather flat with shallow peritremal furrow only near the ostiole (A. sp. 2 - Figs 17, 21: mf); the peritremal surface directed ventrally in its median part, bending posteroventrally in its lateral part (Figs 17, 21: pes). Laterally the peritremal surface reaching the lateral margin of metepisternum and merging with the surface of ventral margin of LES (Fig. 23).

Metathoracic spiracle well developed, long, narrow, nearly parallel-sided (Figs 5-6, 14-17: sp), its lateral margin reaching the evaporatory channel. The entrance to the spiracle protected by simple column-shaped filter processes (Fig. 20: fp).

Evaporatorium developed both on mesopleuron and metapleuron (Figs 5-6, 14-17, 20: ev). Metapleural evaporatorium very large, covering most of metapleuron except for metacetabulum and posterior margin of metepimeron, peritreme, and the very lateral metapleural margin (Figs 5-6, 16-17). Mesopleural evaporatorium limited to mesepimeron, reaching its lateral margin (Figs 5-6, 16-17) and continuing laterad as an impressed groove, the evaporatory channel (Figs 14-15), and ending 

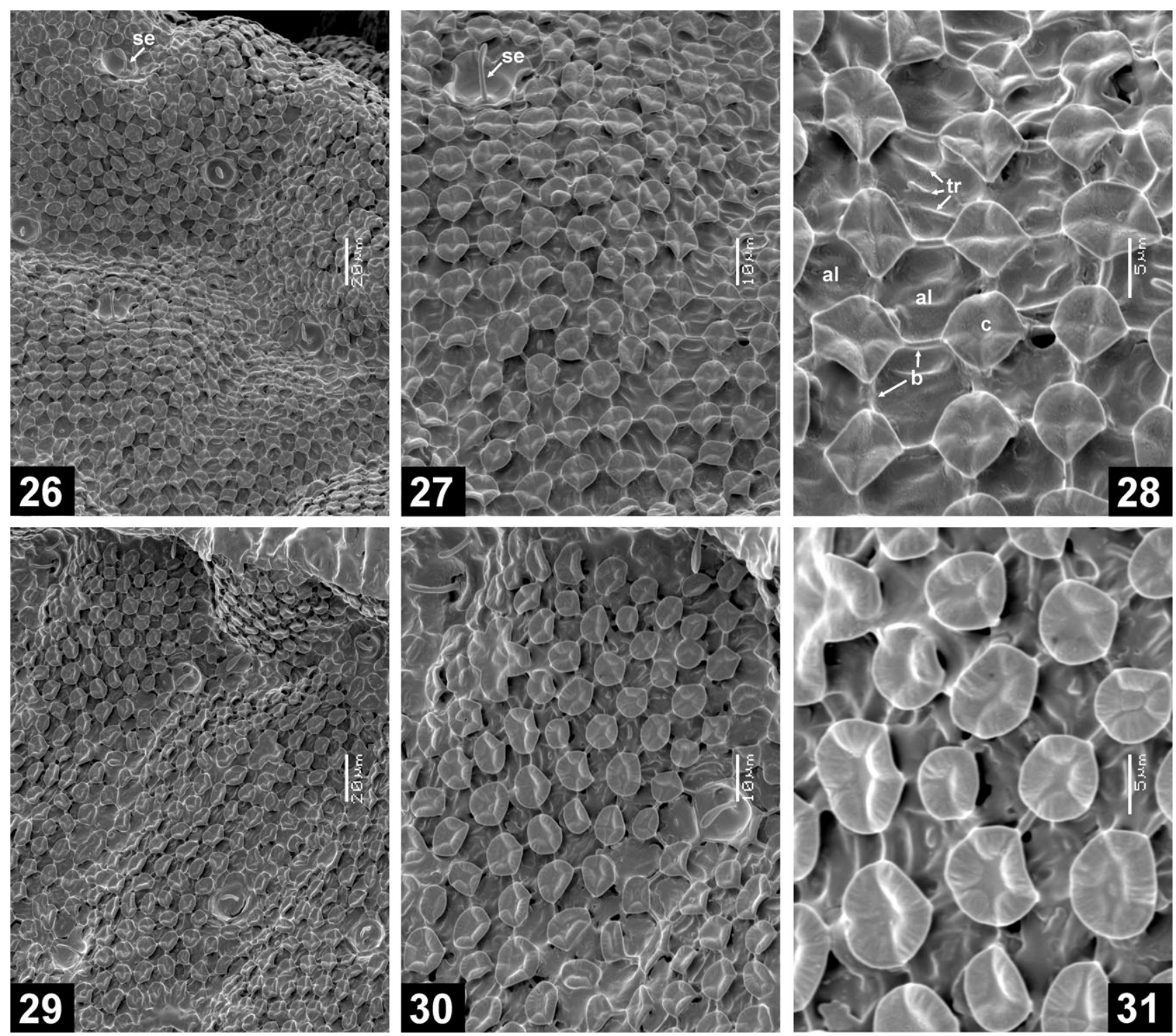

Figs 26-31. Aphylum sp. 2, details of evaporatorium microsculpture: 26-28-metapleural evaporatorium anteriad of peritreme (26 $-600 \times, 27-1200 \times, 28-3000 \times), 29-31$ - metapleural evaporatorium posteriad of peritreme $(29-600 \times, 30-1200 \times, 31-3000 \times)$. Abbreviations: al - alveole, $\mathrm{b}$ - bridges connecting mushroom bodies, $\mathrm{c}$ - cap of mushroom body, se - seta, $\operatorname{tr}-\operatorname{trabeculae}$.

as Y-shaped incision on ventral margin of AMES (Figs 7, 10-12). Evaporatory channel running through the pronotal-exponial tunnel (being part of its roof) and delivering the scent secretion towards the lateral external surface of the body. Gyrification on mesepimeron in a form of shallow furrows directed anterolaterad, on metepisternum one deeper furrow anterior to the peritreme directed laterad, and a series of shallow furrows posteriorly to the peritreme directed caudad (Figs 16-17: gf).

Microsculpture (Figs 20-31). Peritremal surface inside ostiole bearing scale-like microsculpture (Fig. 22: scm), surface of the basal part of peritreme irregularly wrinkled (Figs 21-22, 25: w). The wrinkles nearly longitudinal in the median part (Figs 17, 21: w); apically the wrinkles of peritremal surface more and more shallow, peritremal surface becoming nearly smooth (Figs 16, 23-24: pes). Microsculpture of evaporatorium (Figs 26-31) with characteristic mushroom-like appearance with caps of mush- room bodies quadrangular to nearly round, each cap connected to adjacent mushroom bodies by bridges, most often to four of them (Figs 28, 31: c, b). Alveoles are small, with only few trabeculae present on their bottom (Figs 27-28, 30-31: al, tr). The mushroom bodies and alveoles appearing to be arranged in nearly regular rows, especially when observed under lower magnifications (Figs 26, 29). Scarce clavate setae intermingled among the mushroom bodies (Figs 26-27, 29-30: se).

\section{DISCUSSION}

\section{Taxonomy}

We are aware of the cladistic opinion by Grazia et al. (2008) on a sister-group relationship between the Cyrtocoridae and (Aphylidae and Pentatomidae s. str.). However, we retain the family level ranking of the two former groups preferring at the moment the analytical approach to classification of the high level pentatomoid clades. [For 
a possible sister-group relationship between the Cyrtocoridae (Neotropical) and Aphylidae (Australian) see Davidová-Vilímová \& Štys (1994) and Štys \& DavidováVilímová (2001).] The previous taxonomic history of the Aphylidae was summarized by Štys \& DavidováVilímová (2001) and Cassis \& Gross (2002).

The present knowledge of species-level taxonomy of Aphylum does not allow even a reliable identification of the two species established by Bergroth (1906) and Schouteden (1906a); prior to a revision we cannot rely on any previous species-level data. The diagnostic characters used by Schouteden (1906b) are plastic and more than two species of males are present in material of Aphylum available to us (P. Štys, unpubl.). We have seen several specimens identified as $A$. bergrothi from Queensland and several as $A$. syntheticum from various parts of Australia. However, for the above reasons we do not consider their identification reliable, and call the two specimens examined in this paper " $A$. sp. 1 cf. bergrothi" and " $A$. sp. 2", respectively (see Material and Methods), and the specimen of Aphylum studied by Štys \& DavidováVilímová (2001) “A. sp. 3 cf. syntheticum”.

\section{Morphology of the external scent efferent system}

The external scent efferent system of Aphylum is well developed, including a long, laterally prolonged peritreme, and a very large evaporatorium covering most of the metapleuron and the mesepimeron. Such a situation is not uncommon among the Pentatomoidea (cf. Kment \& Vilímová, 2010a). However, there are some features that ought to be emphasized:

(i) The vestibular scar is missing. Despite the vestibule of the Pentatomoidea being completely closed, the narrow line of a scar-like appearance remains externally visible in place of adhesion of the scent groove margins in several taxa. This scar starts at the anteromedian margin of metacoxal cavity and continues laterally towards the proximal margin of ostiole (Kment \& Vilímová, 2010a, b). The vestibular scar occurs regularly in the Coreoidea, Lygaeoidea, Pyrrhocoroidea, as well as in several families of the Pentatomoidea, i.e., Thaumastellidae, Cydnidae, Thyreocoridae, Parastrachiidae, Phloeidae: Phloeinae, Plataspidae, and Dinidoridae (partim) (e.g. Brindley, 1934; Remold, 1962, 1963; Štys, 1967; Lis, 1994; summary in Kment \& Vilímová, 2010a, b).

The distribution of the vestibular scar in view of the present hypothesis of Pentatomoidea phylogeny (Grazia et al., 2008) indicates that it may be a plesiomorphic character, lost independently in several of the Pentatomoidea clades, e.g. Urostylididae, Tessaratomidae s. 1., Acanthosomatidae, Scutelleridae, and Pentatomidae s. 1. [= Cyrtocoridae + (Aphylidae + Pentatomidae)] (cf. Kment \& Vilímová, 2010b).

(ii) Peritreme reaching lateral margin of metapleuron (metepisternum) and merging with the surface of ventral margin of LES. This is a unique feature of Aphylum, as we have never seen another species of the Pentatomomorpha (P. Kment \& J. Vilímová, pers. observ.) with so extremely prolonged peritreme merging apically with the lateral margin of metapleuron. Moreover, this character is
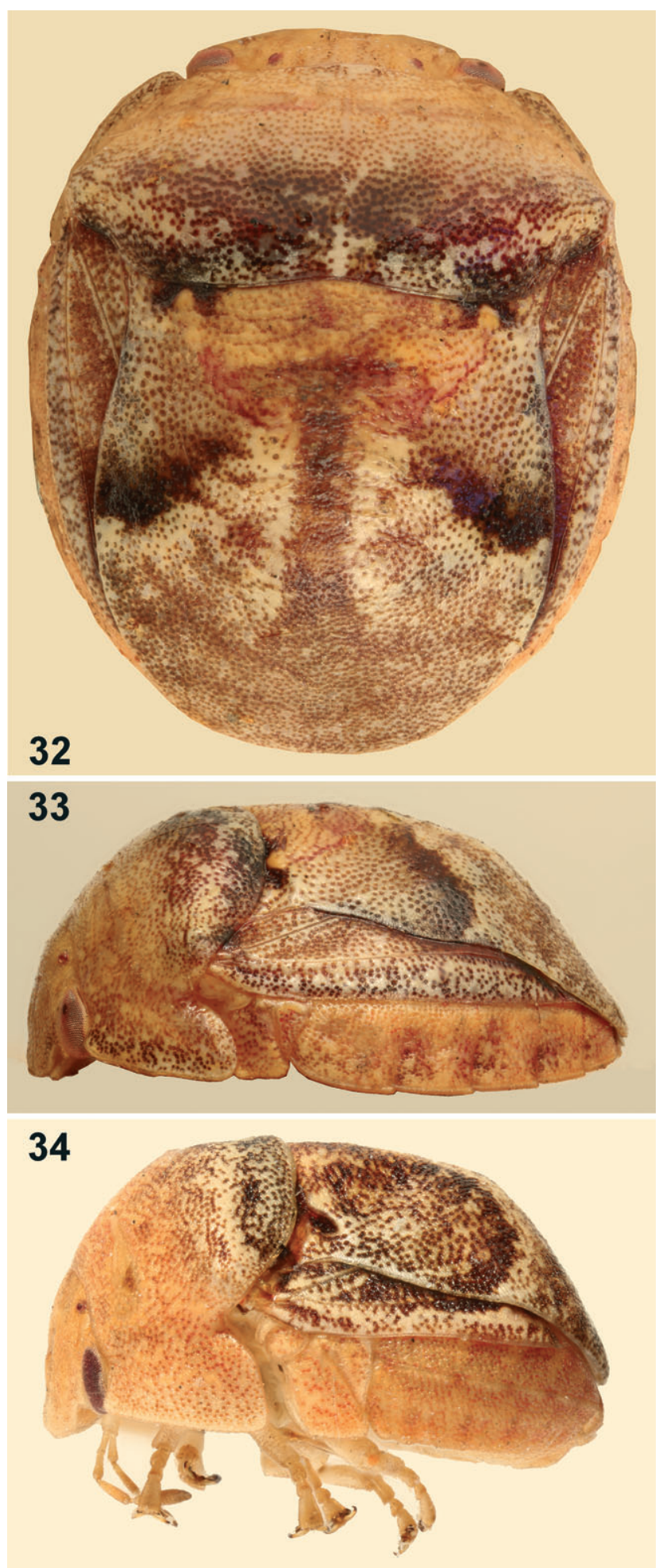

Figs 32-34. Habitus. 32-33 - Aphylum sp. (female, Queensland, Cunnamulla Dist., Nov. 42, N. Geary; coll. Australian National Collection of Insects, Canberra, Australia; body length $5.8 \mathrm{~mm}$ ): 32 - dorsal view, 33 - lateral view. 34 Neoaphylum grossi Štys \& Davidová-Vilímová, 2001 (holotype, female; body length $4.7 \mathrm{~mm}$ ), lateral view.

not shared with Neoaphylum grossi, in which the peritremal apex reaches only to ca. 3/4 of metapleuron width and is gradually fading off apically (cf. Štys \& DavidováVilímová, 2001: Fig. 12). The whole peritreme in 
Aphylum is distinctly elevated above the surrounding thoracic surface, therefore the secretion could easily pass from the peritremal surface to the surrounding cuticle before reaching the lateral end of peritreme; this seems strange considering that peritreme should serve to spread and direct the secretion flow. Without detailed knowledge of how the mechanisms of ejection and spreading the scent gland secretion work in Aphylum we cannot explain the function of its peritreme. The elevation of the peritreme above metepisternal surface is characteristic of Neoaphylum as well, although its peritreme is much shorter.

(iii) Evaporatorium reaching lateral margin of mesepimeron and metepisternum, and continuing as far laterad as ventral surface of AMES. The evaporatorium widely extended and reaching the lateral thoracic margins of both meso- and metapleuron is rather rare among Pentatomoidea but could be found e.g. in Plataspidae, Phloeidae: Serbaninae, some Cydnidae (Amnestus Dallas, 1851) (Kment, 2009; Kment \& Vilímová, 2010a). However, the mycoid surface reaching the external lateral surface of the body (here on ventral surface of AMES) is a unique character of the Aphylidae, being closely connected with the apomorphic structure of the thorax and development of the exponium (see below). This extension of the evaporatorium up to the ventral surface of AMES is further assisted by the development of evaporatory channel in Aphylum*. The term evaporatory channel was defined by Kment \& Vilímová (2010a) as a depressed channel covered with mycoid surface conducting the secretion from the peritreme towards the lateral pleural margin. The evaporatory channel of Aphylum does not fit the definition in full, as it does not start in proximity of the peritreme apex, but at the end of metathoracic spiracle. However, the close association of evaporatory channel with metathoracic spiracle is not unique, occurring also in Triplatyx Horváth, 1904 (Pentatomidae: Pentatominae) (Kment, 2008, as "outlet channel") or in the Aradidae (Usinger \& Matsuda, 1959; Larivière \& Larochelle, 2006).

(iv) The close association of the metathoracic spiracle with the evaporatorium and the external scent efferent system in general (most pronounced e.g. in Tessaratomidae: Tessaratomini) suggests that metathoracic spiracles participate in the defensive process by promoting dispersion of the secretion by means of an exhalation-ventilation process (Carver, 1990; Kment \& Vilímová, 2010b). The detailed studies of this hypothesis, particularly the mechanism of scent excretion, still remain to be conducted. (v) Pattern of the microsculpture of evaporatorium in Aphylum is frequent in Heteroptera, distinctly extending the surface of this area. However, the detailed pattern of mycoid microsculpture of Aphylum is somewhat different from that known in most of the other Heteroptera studied. The caps are quite low and close each to other, connecting bridges are low, the surface of alveoles is almost smooth with only sporadic and inconspicuous trabeculae. The more common heteropteran situation is represented by high caps and high bridges, caps being farther apart allowing thus for larger alveoles, with many high and undulating trabeculae (e.g. Carayon, 1971; Carver, 1990; Kment, 2009; Kment \& Vilímová, 2010a, b). However, we cannot exclude that the absence of trabeculae is only virtual, being caused by an insoluble enamel-like crust covering the mycoid microsculpture - a not unusual condition in the Pentatomoidea.

The evaluation of the detailed differences in mycoid miscrosculpture among different heteropteran species is problematic, considering (i) artifacts of SEM micrographs due to uneven surface of evaporatorium (the gyrification) or contamination of the examined surface, (ii) variability of mycoid surface among different parts of evaporatorium even of the same specimen (cf. Kment \& Vilímová, 2010a: Figs 110 and 111), (iii) limited number of pentatomoidean species with mycoid microsculpture examined under SEM (for references see Kment \& Vilímová, 2010a, b) which is a crucial impediment in determination of plesiomorphic, apomorphic and homoplasious patterns, attempted previously only by Hasan \& Kitching (1993) in a very limited sample of species. The scarce data about this feature do not allow any general suggestion or explanation, we only can conclude that the Aphylum pattern is rather rare.

\section{Morphology of exponium}

The exponium of Aphylum syntheticum was first figured by Bergroth (1906), who identified the sclerites as mesonotum (= AMES), metanotum (= LES) and "Connexiv-Segment" (sic!; in German) (= TES) - i.e. essentially in similar way to Štys \& Davidová-Vilímová (2001), who described and figured the exponium of "Aphylum sp. 3 cf. syntheticum" and Neoaphylum grossi.

Śtys \& Davidová-Vilímová (2001) regarded the homology of AMES and posterior mesal exponial sclerite (PMES) as uncertain, however, they suggested possible origin of AMES from modified mesopleural articulation of forewing. The recent SEM investigation and the discovery of mycoid microsculpture on AMES support origin of this sclerite from dorsal part of metapleuron

\footnotetext{
* Neoaphylum grossi is known from a holotype only (Fig. 34), and, consequently, some of the following observations are tentative and could not have been confirmed by SEM study. The metathoracic spiracle is extremely long, terminating laterally at the midlength of the "modified lateral part of LES" (Štys \& Davidová-Vilímová, 2001: Figs 12, 14). The thoracic sternal and pleural parts are rather brilliant but, nevertheless, the extent of evaporatorium (presumably with mycoid microsculpture) can be estimated owing to degree of lustre (or the lack of it) and appearance of cuticle, as follows: mesepimeron up to its lateral margin; metepisternum up to its lateral margin (probably); "modified lateral part of LES"; AMES; the most lateroventral articulatory sclerite of forewing (in resting position $=$ the most anterior sclerite in spread forewing). The apparent spread of metathoracic gland secretion onto forewing articulatory system in $N$. grossi does not seem to have a parallel among Pentatomomorpha, and is shared by the Dipsocoridae and probably Stemmocryptidae (both Dipsocoromorpha s. str. - P. Štys, unpubl.) only.
} 
(both mesepisternum and mesepimeron) reflected onto dorsum.

The PMES of Neoaphylum is formed from a dorsally turned part of mesepisternum (Štys \& Davidová-Vilímová, 2001). Mesal parts of Neoaphylum AMES and PMES are covered by forewings and accommodates the hypocostal lamina that terminates just at the boundary between PMES and LES. Such a situation could suggest homology of PMES with the posterior part of AMES in Aphylum rather than with mesal part of LES as suggested elsewhere and based on ventral association of PMES. The costal margin of forewing also covers the mesal margins of LES and TES that probably form part of the forewing groove (per analogy with Aphylum).

Štys \& Davidová-Vilímová (2001) hypothesised that LES is of a metepisternal-metapostnotal origin. The metapleural origin of the sclerite is supported by the peritreme ending on ventral face of LES, as the location of peritreme is in general restricted to metathorax (Kment \& Vilímová, 2010a). Unlike in AMES, the mycoid microsculpture does not continue from the metapleural evaporatorium on LES surface, therefore the sclerite most probably has no role in delivery of the scent secretion.

Concerning TES, Štys \& Davidová-Vilímová (2001) suggested its homology with dorsal abdominal laterotergites 1 and 2 .

Despite the three (or four) principal exponial sclerites described in detail previously (Štys \& DavidováVilímová, 2001), we recognize here another functional element in the highly apomorphic structure of aphylid thorax, the pronotal-exponial gap, leaving free space between the posterior margin of the laterally explanate pronotum and anterior margin of the exponium. In Neoaphylum grossi, the pronotum is not closely attached to LES, the pronotal-exponial gap is opened in its entire length, being slightly scimitar-shaped, beginning at the ventral margin of AMES and slightly widening laterally* (Fig. 4: peg) (Štys \& Davidová-Vilímová, 2001). In species of Aphylum the pronotal-exponial gap is laterally reduced by posterior pronotal margin overlapping over anterior margin of LES, being apparent only in its basal part and appearing as a narrow opening between AMES and pronotum (the pronotal-exponial tunnel). The pronotal-exponial gap or tunnel represents the only interruption of the otherwise homogenous "bonnet" of laterally expanded parts of pronotum, exponium and abdominal laterotergites covering and protecting the ventral side of the body when the bug is closely attached to substrate.

\section{Potential function of apomorphic thoracic structures of Aphylidae}

The Aphylidae are rather hemispherical bugs of armoured appearance owing to the hypertrophied mesoscutellum covering most of the posterior parts of dorsum and to the expanded lateral region of both the thorax (pro- notum, exponium) and abdomen (laterotergites) protecting the venter (Figs 32-34). Ejection of the pungent secretion of the metathoracic scent glands is the common defensive reaction in Heteroptera (e.g. Remold, 1962, 1963; Staddon, 1986). However, the wide and flattened body venter and especially the ventrally expanded lateral margins in Aphylidae would prevent effective spreading of the secretion laterally towards a potential predator. The thorax of the Aphylidae has been uniquely transformed: its dorsal thoracic margins have been expanded ventrad allowing for a complete coverage of venter of the body when resting on substrate, and retaining at the same time the possibility of chemical defence by metathoracic scent glands. The modified structures of the lateroventral thoracic parts (mesopleuron reflected dorsad and extending as AMES or AMES + PMES onto the external suface of the resting body), jointly with the modified external scent efferent system (evaporatory channel, mycoid microsculpture extending onto AMES) and the pronotalexponial gap/tunnel, form a free passage for the scent secretion. It may spread from the ventrally situated ostiole to lateral external surface of the body. The autapomorphic structure of the thorax in Aphylidae probably represents a compromise allowing a coexistence of two different but complementary mechanisms of defence.

The thoracic structure of Aphylidae, including the autapomorphic exponium, is so unique that comparison with other Heteroptera is problematic. Hemispherical bugs with body shape similar to Aphylidae are not rare, such body shape is among the Pentatomomorpha characteristic of the pentatomoid families Lestoniidae (Australian), Canopidae, Megarididae (both Neotropical), Plataspidae (Old World), and occurs also in the Scutelleridae (e.g., Sphaerocorini) and Pentatomidae (e.g., some Discocephalinae). Undoubtedly, the strongly sclerotized and strongly convex body with nearly flat to concave venter provides a strong mechanical protection against small predators (like ants) and ovipositing parasitoids. However, the mechanical protection can hardly replace the chemical antipredatory mechanisms, if larger active predators (like insectivorous birds, small mammals, lizards and geckos) are involved. This is also suggested by the diverse architecture of the external scent efferent system in those Pentatomoidea provided with a wide and flat ventral side of the body. We can identify several modifications of how the external scent efferent system changes in relation to the problem of effectively spreading scent secretion.

First, the external scent efferent system may have been reduced to a different degree, occasionally resulting in complete reduction of the metathoracic scent glands (some Scutelleridae - Kment, 2009). Such bugs must relay on mechanical protection apparently sufficient for coping with their natural enemies. Among bugs with hemispherical body, such a situation exists in Megarididae with minute ostiole only and complete reduction of peritreme and evaporatorium (see McAtee \& Malloch,

\footnotetext{
* It seems that pronotum of the single known specimen of Neoaphylum grossi is artificially shifted slightly forwards, and the widely opened pronotal-exponial gap may be an artifact (Fig. 34). More specimens of this enigmatic species are needed to elucidate this point.
} 
1928; McDonald, 1979). In Lestoniidae, the ventral surface of the body is flat and meso- and metathorax are laterally covered by explanate lateral margins of pronotum and costal area of hemelytron (China, 1955; McDonald, 1969), a situation resembling that of the Aphylidae. However unlike them, Lestoniidae also show a remarkable reduction of the external scent efferent system, which moreover differs considerably between the two included species (peritreme and small evaporatorium developed in Lestonia grossi McDonald, 1969 versus peritreme and evaporatorium missing in L. haustorifera China, 1955) (McDonald, 1969; Kment, 2009).

The second possible method is exemplified by a well developed external scent efferent system with tendency of its particular components to shift (usually the ostiole), prolong (usually the peritreme) or extend (usually the evaporatorium) towards lateral body margin. Such a trend is evident in most Plataspidae, in which (a) the ostiole is shifted laterad to ca. half-width or one-third of metapleuron, (b) the peritreme (sometimes prolonged) reaches near the lateral margin of metapleuron; (c) an analogous pseudoperitremal structure has evolved in posterolateral angle of mesopleuron, and (d) the evaporatorium is extended, covering almost entire thoracic venter (Kment, 2009; Kment \& Vilímová, 2010a, b).

In the Canopidae, the situation combines the two methods - the peritreme is considerably reduced, but evaporatorium is in some species extended laterally and reaches the lateral margin of mesopleuron (McAtee \& Malloch, 1928; Kment, 2009). Both the methods, either reduction of the external scent efferent system (and thus the chemical defence) or its remarkable development with lateral shift of its particular components, can be observed also in Aradidae remarkable for their very flat body (cf. Usinger \& Matsuda, 1959; Larivière \& Larochelle, 2006).

Unfortunately, nearly nothing is known about the biology of Aphylidae. Cassis \& Gross (2002) classified all the three known species of Aphylidae as arboreal, herbivore, terrestrial and volant. Gross (1975) mentioned that "both [Aphylum] species certainly pass a great deal of their time under Eucalyptus bark". The specimens of Aphylum syntethicum were collected under bark of Eucalyptus camaldulensis Dehnh. (Myrtaceae); at first sight they could easily be mistaken for beetles of the genus Paropsis Jenyns, 1841 (Chrysomelidae: Chrysomelinae) which are also common under the bark of Eucalyptus spp. (Gross, 1975). The behaviour of Aphylidae is unknown and we do not know what predators may endanger them. The obvious ones, ants and spiders, live in the same habitat that is also easily accessible to adults of hymenopteran parasitoids (P. Štys, pers. observ. of the microhabitat).

Moreover, there is also no evidence of Aphylidae having or lacking parental care, various kinds of which are widespread in Pentatomoidea (Cydnidae, Parastrachiidae, Phloeidae, Tessaratomidae, Acanthosomatidae, Scutelleridae, Dinidoridae, Pentatomidae) (summary in Tallamy \& Schaefer, 1997). If parental care indeed exists in the Aphylidae, their specialized scent efferent system and related defensive strategies may have an essential role in guarding the eggs and/or young larvae, especially when hidden under the parent's body.

ACKNOWLEDGEMENTS. We thank M. Hyliš (Charles University, Praha) for kind assistance during work with SEM. We are greatly indebted to G. Cassis and T.A. Weir allowing PŠ to borrow specimens of Aphylidae from the Australian Museum (Sydney) and Australian National Insect Collection (Canberra), respectively. M. Fikáček (National Museum, Praha) kindly helped us with scanning of the figures. This work was partly supported by the following grants: Ministry of Culture MK00002327201 to National Museum, Praha (PK), Ministry of Education MSM0021620828 to Charles University, Praha (JV), and Czech Science Foundation 206/07/0507 (PŠ). Last but not least we are indebted to D. Rédei (Hungarian Natural History Museum, Hungary) and two anonymous referees for thoughtful comments and criticism of the earlier version of the manuscript.

\section{REFERENCES}

Aldrich J.R. 1988: Chemical ecology of the Heteroptera. Annu. Rev. Entomol. 33: 211-238.

Bergroth E. 1906: Aphylinae und Hyocephalinae, zwei neue Hemipteren-Subfamilien. Zool. Anz. 29: 644-649.

BRINDLEY M.D.H. 1934: On the metasternum and pleuron of Heteroptera. Trans. Entomol. Soc. Lond. 82: 43-50.

CARAYON J. 1971: Notes et documents sur l'appareil odorant métathoracique des Hémiptères. Ann. Soc. Entomol. Fr. (N.S.) 7: 737-770.

CARVER M. 1990: Integumental morphology of the ventral thoracic scent gland system of Poecilometis longicornis (Dallas) (Hemiptera: Pentatomidae). Intern. J. Insect Morphol. Embryol. 19: 319-321.

Cassis G. \& Gross G.F. 2002: Hemiptera: Heteroptera (Pentatomomorpha). In Houston W.W.K. \& Wells A. (eds): Zoological Catalogue of Australia. Vol. 27.3B. CSIRO, Melbourne, xiv $+737 \mathrm{pp}$.

China W.E. 1955: A new genus and species representing a new subfamily of Plataspidae, with notes on the Aphylidae (Hemiptera, Heteroptera). Ann. Mag. Nat. Hist. (Ser. 12) 8: 204-210.

DAVIDOVÁ-VILímovÁ J. \& ŠTYS P. 1994: Diversity and variation of trichobothrial patterns in adult Podopinae (Heteroptera: Pentatomidae). Acta Univ. Carol. Biol. 37[1993]: 33-72.

Grazia J., Schun R.T., Wheeler W.C. 2008: Phylogenetic relationships of family groups in Pentatomoidea based on morphology and DNA sequences (Insecta: Heteroptera). Cladistics 24: 1-45.

Gross G.F. 1975: Plant-feeding and other Bugs (Hemiptera) of South Australia. Heteroptera - Part I. A.B. Goverment Printer, James, South Australia, vi +250 pp.

Gross G.F. 1991: Superfamily Pentatomoidea. In CSIRO (ed.): Insects of Australia. A Textbook for Students and Research Workers. Vol. 1. 2nd ed. Melbourne University Press, Carlton, Victoria, pp. 429-509.

Hasan S.A. \& Kitching I.J. 1993: A cladistic analysis of the tribes of the Pentatomidae (Heteroptera). Jap. J. Entomol. 61: 651-669.

KMEnT P. 2008: A revision of the endemic Madagascan genus Triplatyx (Hemiptera: Heteroptera: Pentatomidae). Acta Entomol. Mus. Natn. Pragae 48: 543-582.

KMent P. 2009: Comparative Morphology of Structures Associated with Metathoracic Scent Glands in Heteroptera. Ph.D. thesis. Charles University, Prague, 178 pp. 
Kment P. \& Vilímová J. 2010a: Thoracic scent efferent system of the Pentatomoidea (Hemiptera: Heteroptera): a review of terminology. Zootaxa 2706: 1-77.

Kment P. \& Vilímová J. 2010b: Thoracic scent efferent system of the Tessaratomidae sensu lato (Hemiptera: Heteroptera: Pentatomoidea) with reference to the phylogeny of the family. Zootaxa 2363: 1-59.

Larivière M.-C. \& Larochelle A. 2006: An overview of flat bug genera (Hemiptera, Aradidae) from New Zealand, with considerations on faunal diversification and affinities. Denisia 19: 181-214.

Lis J.A. 1994: A Revision of Oriental Burrower Bugs (Heteroptera: Cydnidae). Upper Silesian Museum, Bytom, 349 pp.

McAtee W.L. \& Malloch J.R. 1928: Synopsis of pentatomid bugs of the subfamilies Megaridinae and Canopinae. Proc. U.S. Natn. Mus. 72(25): 1-21+2 pls.

McDonald F.J.D. 1969: A new species of Lestoniidae (Hemiptera). Pacific Insects 11: 187-190.

McDonald F.J.D. 1979: A new species of Megaris and the status of the Megarididae McAtee \& Malloch and Canopidae Amyot \& Serville (Hemiptera: Pentatomoidea). J. N. Y. Entomol. Soc. 87: 42-54.

Remold H. 1962: Über die biologische Bedeutung der Duftdrüsen bei den Landwanzen (Geocorisae). Z. Vergleich. Physiol. 45: 636-694.

Remold H. 1963: Scent-glands of land bugs, their physiology and biological function. Nature 198: 764-768.

SCHOUteden H. 1906a: Une nouvelle espèce du genre Aphylum. Ann. Soc. Entomol. Belg. 50: 215-216.

Schouteden H. 1906b: Heteroptera. Fam. Pentatomidae. Subfam. Aphylinae. In Wytsman P. (ed.): Genera Insectorum. 47 me Fascicule. P. Wytsman, Bruxelles, 4 pp. +1 pl.
Schun R.T. \& Slater J.A. 1995: True Bugs of the World (Hemiptera: Heteroptera). Classification and Natural History. Cornell University Press, Ithaca and London, xii +377 pp.

Staddon B.W. 1979: The scent glands of Heteroptera. $A d v$. Insect. Physiol. 14: 351-418.

Staddon B.W. 1986: Biology of scent glands in the HemipteraHeteroptera. Ann. Soc. Entomol. Fr. (N.S.) 22: 183-190.

ŠTYS P. 1967: Monograph of Malcinae, with reconsideration of morphology and phylogeny of related groups (Heteroptera, Malcidae). Acta Entomol. Mus. Natn. Pragae 37: 351-516.

Štys P. \& Davidová-Vilímová J. 2001: A new genus and species of the Aphylidae (Heteroptera: Pentatomoidea) from Western Australia, and its unique architecture of the abdomen. Acta Soc. Zool. Bohem. 65: 105-126.

Tallamy D.W. \& Schaefer C.W. 1997: Maternal care in the Hemiptera: ancestry, alternatives, and current adaptive value. In Choe J.C. \& Crespi B.J. (eds): The Evolution of Social Behavior in Insects and Arachnids. Cambridge University Press, Cambridge, pp. 94-115.

Usinger R.L. \& MATSUdA R. 1959: Classification of the Aradidae (Hemiptera-Heteroptera). British Museum (Natural History), London, vii $+410 \mathrm{pp}$.

WeIRAUCH C. 2006a: Metathoracic glands and associated evaporatory structures in Reduvioidea (Heteroptera: Cimicomorpha), with observation on the mode of function of the metacoxal comb. Eur. J. Entomol. 103: 97-108.

WeIRAUCH C. 2006b: Dorsal abdominal glands in adult Reduviidae (Heteroptera, Cimicomorpha). Mitt. Mus. Naturkd. Berlin, Dtsch. Entomol. Z. 53: 91-102.

Received July 22, 2011; revised and accepted November 1, 2011 